\title{
Application of IFRS/Ind AS in Indian Public Sector Banks: An Analysis
}

\author{
Raj S Dhankar ${ }^{1,2, *}$, Barnali Chaklader ${ }^{3}$, Amit Gupta $^{4}$ \\ ${ }^{1}$ Amity University, Raipur, Chhattisgarh, India \\ ${ }^{2}$ Faculty of Management Studies, University of Delhi, Delhi, India \\ ${ }^{3}$ Professor of Finance \& Accounting, International Management Institute, New Delhi, India \\ ${ }^{4}$ Faculty of Management Studies, University of Delhi, New Delhi, India
}

Copyright $(\mathrm{C} 2018$ by authors, all rights reserved. Authors agree that this article remains permanently open access under the terms of the Creative Commons Attribution License 4.0 International License

\begin{abstract}
This study examines the perception of Public Sector Banks in India towards the implementation of IFRS. The paper provides insights into the IFRS adoption process based on a questionnaire sent to Public Sector Banks in India in 2015. The 291 responses received indicate: (1) Loan Impairment will affect the bank's financial performances; (2) transparency of the results of the Banks will be increased; (3) global operations of the Banks will be impacted in positive direction; (4) the accessibility of the global capital market will increase; (5) corporate governance of the banks will increase; (6) the quality of financial information provided to the regulators and shareholders will improve; (7) the comparability aspect of financial statements will increase; (8) market capitalization of banks will improve; (9) the training needs of the staff will increase; (10) the opportunities for the accounting professionals will expand; (11) the flow of FDI in the banking sector will increase.
\end{abstract}

Keywords Public Sector Banks (PSBs), IFRS, Ind AS, ICAI, NACAS, IAS

\section{Introduction}

International Financial Reporting Standards (IFRS) are a single set of high-quality, understandable, enforceable and globally accepted financial reporting standards based upon clearly articulated principles. These standards enable the investors and other users of the financial statements to compare the financial statements on a like-for -like basis with their international peers.

In India, Accounting Standards are formulated by the Council of the ICAI (Institute of Chartered Accountants of India) through its Accounting Standards Board. Thereafter, those Accounting Standards are considered by the National Advisory Committee on Accounting Standards (NACAS) of the Ministry of Corporate Affairs constituted under the Indian Companies Act, 1956 (now amended in 2013), which recommends the Standards to the Central Government for notifying under the Act. The Government, on accepting the recommendation of the Committee, notifies the Standards under the Act by publishing them in the Official Gazette.

At present, 28 Accounting Standards, which are based on old IASs, have been notified under the Companies Act, 1956. In a move towards convergence with IFRSs, in 2007 , the ICAI commenced the process of developing a complete set of Accounting Standards that are 'converged with' IFRSs - to be known as Indian Accounting Standards or Ind ASs. India has decided to converge its accounting standards with IFRSs issued by IASB instead of adoption of IFRSs. Thirty-five Ind ASs corresponding to IFRS in force on 1April, 2011 (with the exception of IFRS 9 Financial Instruments, IAS 26 Accounting and Reporting by Retirement Benefit Plans, and IAS 41 Agriculture) were placed on the website of the Ministry of Corporate Affairs. However, they have not been notified under the Companies Act, 1956.

Ministry of Corporate Affairs, Government of India issued a press release on January 18, 2016, wherein a roadmap for adopting IFRS/Ind AS was announced for the scheduled commercial banks (excluding regional rural banks), insurers/insurance companies and non-banking finance companies. Thus, now, it has become mandatory to implement IFRS/Ind AS for accounting period beginning from April 1, 2018 onwards for the followings:

1) Scheduled commercial banks (excluding regional rural banks).

2) All India term lending refinancing institutions (i.e. EXIM Bank, NABARD, NHB and SIDBI).

3) Insurers/insurance companies.

NBFCs will be required to prepare IFRS/Ind AS based financial statements in two phases: 
Phase I: mandatory for accounting period beginning from April 1, 2018 onwards for NBFCs having net worth of Rs. 50 Billion or more.

Phase II: mandatory for accounting period beginning from April 1, 2019 onwards for:

1) NBFCs whose equity and/or debt are listed or are in the process of listing on any stock exchange in India or outside India and having net worth less than Rs. 50 Billion

2) NBFCs that are unlisted companies and having net worth of Rs. 25 Billion or more but less than Rs. 50 Billion.

The objective of this study is to examine the process of implementing IFRS by Public Sector Banks in India, including the approach which these PSBs take to conversion, the impact of adopting IFRS on the financial statements, and the perceived benefits and challenges of implementing IFRS. Understanding these issues should be helpful to all users of the financial statements, including regulators facing decisions regarding individual accounts and unlisted companies.

The remainder of this paper is organized as follows. Section 2 discusses relevant prior research. Research methodology used is presented in section 3. Section 4 talks about the research design. Discussion and limitations are covered in section 5 .

\section{Literature Review}

Several studies have addressed issues related to accounting harmonization in foreign countries like Europe, USA, China, Russia etc. and its impact on comparability and transparency of financial statements. In India also, a number of studies have been conducted on the impact of implementation of IFRS/Ind AS.

Jeanjean, Thomas and Stolowy, Herve (2008) analyzed in their work whether the mandatory introduction of IFRS standards had an impact on earning quality and more precisely on earning management by studying 3 countries viz. France, UK and Australia. They find that pervasiveness of earning management did not decline and in fact increased in France (behavioral issues). They confirm that sharing rules are not sufficient in itself to create a common business language but management incentives and national institutional factors play an important role in framing financial reporting characteristics. K S, Muthupandian (2008) analyzed the current status of implementation or more specifically convergence of IFRS with local gap in various countries viz, US (fully converged), Canada (2011), Japan (2011), China (2007), Russia (2004), Brazil (2010), Ghana (2007), Korea (2011), Hong Kong (2005), Philippines (2005), Australia (2005), New Zealand (2007), Singapore (2003), India (not yet converged).

Similarly, Chan, Wai-Meng and Devi Sushila S. (2010) analyzed the impact of IFRS on the divisible profits by taking the corporate law's definition of divisible profits in 6 countries viz. UK, Australia, New Zealand, Singapore (all converged with IFRS ), India and Malaysia (not yet converged with IFRS). They concluded that IFRS will disturb the definition of divisible profits by including unrealized gains based on fair accounting into the arena of profits and thus may not be in the best interest of companies. Agostino, Mariarosaria, Drago, Danilo and Silipo, B., Damiano (2010) investigated the market valuation of accounting information in the European banking industry before and after the adoption of IFRS and they found that introduction of IFRS enhanced the information contents of both earnings and book value for more transparent banks. By contrast, less transparent entities did not experienced significant increase in the value relevance of the book value. Cascino, Stefano and Gassen, Joachim (2010) suggested that while mandatory adoption of IFRS increases the comparability of some prominent balance sheet line items across countries, it has no clear effect on the cross-country comparability of earnings attributes. They investigated the IFRS measurement and disclosure compliance choices for a hand collected sample of German and Italian firms and they found that predictable country, region and firm level incentives continue to shape the outcome of the financial reporting process and thus limit the cross-sectional comparability of financial accounting information.

Swaminathan, Shobhana and Sindhu (2011) described the effects on financial statements of the convergence to IFRS by taking a case study on Wipro Technologies Inc. and concluded that IFRS is fair value oriented and balance sheet oriented accounting where there are more transparent disclosures and Indian GAAP has conservative approach. Firoz, Mohammad, Aziz, Ansari, Akhtar, Kahkashan (2011) described the impact of IFRS on Indian banking sector by taking various areas like compliance burden, Tax reporting practices, Information Technology, Financial Instruments, HR, Impairment in advances, Investments, Derivatives and Hedge Accounting, Consolidation of Financial Statements. Lopez-Espinosa, Morino, A., Perez de Gracia, Fernando (2011) highlighted the impact of accounting standards on Net Interest Margin (NIM) by using multi way cluster estimation methodology and cross sectional analysis across 15 different countries (Argentina, Belgium, Brazil, France, Germany, Indonesia, Japan, Mexico, Netherland, Poland, Republic of Korea, Russia, Spain, UK, US) during 1999-2008 period with annual data. They concluded that accounting numbers under IFRS are of high quality which results into reduced NIM which they observed is good for the country. Bhattacharjee, Dipanjan (2011) presented in his conceptual paper the adoption of IFRS in India is associated with reduced earning management which has been defined as "the active manipulation of earnings towards a predetermined target". He concluded that just focusing on accounting standards 
alone is misleading and incomplete. He found that although accounting standards may control earnings management in some cases, it doesn't necessarily means that a country with high quality accounting standards will also have high-quality reported financial information and thus low-earning management. Cole, Vicky, Branson, Joel and Breesch, Diane (2011) contributed by determining by what extent auditors, analysts and other users of European IFRS financial statements believed that these statements were comparable and what they perceived to be most important problem areas when it comes to comparability. They concluded that only $41 \%$ of respondents believed that all European IFRS financial statements are comparable. With respect to comparability, respondents perceived 13 areas as problematic like derivative financial instruments and hedging, Fair Value Measurement, impairment of financial assets, critical judgments and key sources of estimating uncertainty and goodwill, etc. The 3 main issues that appeared in all 13 problematic areas were interpretation differences, subjectivity and disclosure differences, related to both content and location within the financial statements. Jain, Pawan (2011) tried to analyze the available information on IFRS in India. He also discussed IFRS adoption in India and its utility, challenges and possible ways for overcoming those challenges in the implementation of IFRS in India. McEnroe, E., John, \& Sullivan, Mark (2011) reported on the results of the survey of individual investors' attitude towards the adoption of IFRS by the non-US Issuer and consequently exempting them to reconcile to US-GAAP. They concluded that US investors are satisfied with the current US accounting model and do not desire a movement toward the adoption of IFRS.

Thapa, Shankar (2012) discussed in his conceptual paper, the impact of IFRS on Indian Banking Industry by specifying the benefits and challenges. Benefits specified are better global comparability, better access to international capital market and lower cost of capital, easy cross border listing, avoidance of multiple reporting, better quality of financial reporting, economic growth, and opportunities for accounting professionals. On the other hand, challenges of IFRS specified are technical challenges (such as loan impairment, hedge accounting, fair value, consolidation of financial statements, financial instruments, tax reporting practices) and other challenges (such as amendment to existing laws, shortage of trained \& experienced resources, creation of awareness, measurement of business performance, complexity in financial reporting and increased initial costs).

Papadamou, Stephanos and Tzivinikos, Trifon (2012) estimated market, exchange rate and interest rate risk of Greek Financial Institutions and to explore the relationship between market-based measures of risk and accounting variables before and after the adoption of IFRS to examine whether IFRS introduction enhances the information contents of accounting data. They concluded that only market risk affects the Greek banks over the period 2000-2009, while the interest rate and exchange rate risk affects them occasionally. Further, they concluded that the transition towards more transparent accounting systems increases the risk relevance of accounting variables. Lasmin (2012) examined the unwanted effects of IFRS adoption on international trade and investments in developing countries and concluded that adopting IFRS doesn't significantly lead to higher volumes of international trade and investments in developing countries due to various difficulties faced by these countries in adopting IFRS. Gordon, Lawrence, A., Loeb, Martin, P., and Zhu, Wenjie (2012) assessed the impact of adopting IFRS on the overall country FDI inflows and to determine if this impact varies based on whether a country is classified as having a developing or developed economy. Based on an empirical study, they found that the overall FDI inflows are positively associated with a country's decision to adopt IFRS, but only for the developing economies and not for the developed economies. Ramanna, Karthik (2012) stated that the politics of the country influence its reporting standards. He justified his idea by taking example of Canada, China and India. In terms of India, he stated that India is inclined towards the 'convergence' of IFRS and not towards 'harmonisation' of IFRS. He further stated that convergence based IFRS harmonization can be viewed as posing a serious threat to the conceptual goal of 'one global accounting'.

\section{Research Methodology}

In the current research, quantitative research methodology has been used. Both univariate and multivariate techniques have been used to meet the objectives of the research. The current study starts with an objective approach to the research at each step of the research process. As the aim was to find out major issues and challenges in implementation of IFRS system in India so first an attempt was made to find out an instrument that can identify these issues and challenges objectively. Since no satisfactory instrument was found so a decision was made to construct the questionnaire that can help in identifying the major issues and challenges in implementation of IFRS system India.

\subsection{Instrument Development}

A questionnaire was developed based on the review of existing literature, feedback of experts and personal experiences of the researchers that can identify the key human perception and other issues involved in implementation of IFRS system in India. It contained 32 items measuring various aspects of implementation of IFRS accounting standards, like awareness of banking staff about the IFRS accounting standards, precursors and prospects of implementing such measures among others. 
However, a significant portion of the questionnaire was devoted to assessing the impact of implementation of IFRS accounting system. It was hypothesized that human factors like one's own perception or attitude about such standards vis-a-vis the effect on the banking process will be the important determinants of perceived impact of implementation of such accounting standards. Also, since IFRS accounting norms are voluntary in nature (up to 2016 for banks) for the purpose of adoption so the perception of subjects responding the survey will be of importance.

\subsection{Research Design}

Research design refers to the overall plan of the experiment or its blueprint. In the current research the one major research design that has been used is known as between group design. Between Group Design is a kind of research design in which variances in the properties are compared across the groups. In the current research there were many sub-groups based on age, gender, experience, designation and type of bank and it was important for the purpose of research to find out whether the perceived differences in the impact of implementation of IFRS system are stemming from the demographic differences of the participants. To test this, different sub-groups were created and they were compared by using suitable statistical tests which are discussed in the following sections.

Another type of research design which might be implied within this research can be termed as correlational research design. Though correlation has not directly been used in the research but the linear regression model has been used to see if demographic factors are having any causative impact on the dependent variable, i.e., perceived impact of the implementation of IFRS accounting standards in India. Regression models are built over the correlational matrix so it's important to show that the variables are significantly correlated with each other, and if so, there is a suitable case for going for regression analysis.

Another way of looking at the research design of this research can be looking at it through the exploratory glass. Since the major aim of current research was to find out or explore the underlying latent factors that might be determining a subjects' perception toward the impact of implementation of IFRS accounting standards in Indian context, so an exploratory research design has also been utilized in later parts of research. To fulfill this objective an exploratory factor analysis has been carried out whose details with major statistical treatment has been discussed in following sections.

\subsection{Sampling}

Of the two available methods of sampling, i.e., probability and non-probability sampling, purposive sampling method has been followed which is a type of non-probability sampling method. The probability sampling method has not been followed because it was not possible to exercise randomization of banking employees or professionals responding to the questionnaires based on some suitable probability criteria. To approach the suitable subjects for filling the questionnaire permission has to be taken from the relevant organizations and the choice of subject was dependent on the convenience of access and the suitability of the subjects for the research diagnosis. Hence, purposive sampling method has been followed in the research.

\subsection{Sample Size}

In the current study, data was collected from 301 subjects, out of which responses of 291 subjects were found to be valid. So, the sample size for current research can be called to 291. The questionnaire that has been used in the research contained 32 items of which three items were deleted before going for item analysis as their response patterns were completely different as compared to other items of scale.

Another major statistical technique used in the current research was linear regression containing 5 predictors (gender, age, designation, organization, experience) and one dependent variable (perceived impact of implementation of IFRS accounting standards). The sample size sufficiency for this was calculated by using another software package called G-power which for a moderated effect size (.15) and $\alpha=.05$ for 5 predictors gave a sample size of 138 sufficient for carrying out the linear regression analysis with power of .95 . Graphical representation for the central and non-central distribution for this has been shown in Figure 1 (in Appendix).

The actual sample size used for regression analysis in the research was 291 which are more than the prescribed criteria obtained after power analysis, so we can say sample size was sufficient for all kind of major statistical tests employed in the current research.

\subsection{Variables in the Study}

The demographic variables like age, gender, designation, geographical region, type of bank have been the independent variable of the study while the perceived impact of implementation of IFRS accounting standards was the dependent variable. The dependent variable was created after doing item analysis and factor analysis of the items of the questionnaire. The items that showed significant reliability and suitable factor structure after factor analysis were added to create the perceived impact factor. The demographic variables have been measured on nominal and ordinal scales of measurement while the dependent variable was measured on the interval scale of measurement. The Table 1 (in appendix) gives the details of variables in the study. 


\subsection{Data Collection}

The data was collected from all major bank (PSBs) employees across all major geographical regions of India. The detailed description of all these banks along with their number of respondents and location has been given in the following section. The data was collected after taking permission from the concerned bank and briefing subjects about the purpose of research. Both electronic as well as in-person method for data collection was used wherever were appropriate for the situation.

\subsection{The Research Hypotheses}

As stated above since the research was exploratory nature so no specific hypothesis were tested for group differences. However following research hypotheses were implied and confirmed after the analysis:

H1: Demographic variables (like age, gender, experience, designation, and type of organization) have causal effect on the way employees perceive IFRS accounting norms will impact Indian banking sector.

Hypothesis $\mathrm{H} 1$ can be further broken down into sub-hypotheses specifying each demographic variable separately vis-a-vis its relationship with dependent variable viz.

H1a: Age of employees has causal effect on the way employees perceive IFRS accounting norms will impact Indian banking sector.

H1b: Gender of employees has causal effect on the way employees perceive IFRS accounting norms will impact Indian banking sector.

H1c: Years of work experience of employees has causal effect on the way employees perceive IFRS accounting norms will impact Indian banking sector.

H1d: Designation of employees has causal effect on the way employees perceive IFRS accounting norms will impact Indian banking sector.

H1e: Type of bank/organization has causal effect on the way employees perceive IFRS accounting norms will impact Indian banking sector.

H2: There are underlying factors affecting employees' perception of impact of implementing IFRS accounting norms on Indian banking sector.

\section{Data Analysis}

\subsection{Sample Characteristics}

The sample for the study consisted of officer level employees working in the banking sector of Indian public sector banks. The officer level staff of the banking sector that was aware about the implementation of International Financial Reporting Standard was focus of the sample. However other finance professionals like Chartered Accountants and ICWAs who were also aware and dealing with the IFRS were also considered for inclusion in the sample. A total number of 500 professionals were contacted out of which 301 number were responded, thus giving a total response rate of 60.20 percent.

\subsubsection{Demographic Profile}

The demographic profile of the subjects in the current study is shown in the table below with relevant statistics. The demographics were recorded based on gender, age, designation, experience and type of bank. The result shows that males were overrepresented $(64.90 \%)$ as compared to females $(35.10 \%)$. The age taken was between 21 to 64 years which was further categorized into five categories viz. 21 to 24 years, 25 to 34 years, 35 to 44 years, 45 to 54 years, 55 years to 64 years. The frequency and percentage of respondent in each of these categories is shown in the Table 2 (in Appendix).

The experience range of subjects varied from fresher to 30 years which was subdivided into experience ranges of five years i.e., 0 to 5 years, 6 to 10 years, 11 to 15 years, 16 to 20 years, 21 to 25 years, and 26 to 30 years. Freshers were slightly overrepresented in the sample $(33.33 \%)$ followed by the 5 to 10 years of experience group (19.90\%). The rest of the experience group contained the 8 to $10 \%$ subjects in each experience category. Designation was another demographic variable. Designation of subjects ranges from Officer to Manager, Senior Manager, Chief Manager, AGM, DGM and CMD. The frequency percentage of subjects in each designation categories is shown in the table 8.1. AGM, DGM and CMD seem to be underrepresented in the sample as compared to other managerial level staff. The reason for this was the inaccessibility of higher level staff for responding to the questionnaires.

The data was collected from 20 nationalized and other public sector banks working in India whose frequency, percentage and graphical representation of the counts are shown in the table 2 and figure 2. Punjab national bank (30), followed by Dena bank (27), State bank of India (23) and Punjab and Sindh bank (20) respondents are slightly overrepresented as compared to other banks. The details statistics can be seen from the Figure 2 (in Appendix).

\subsection{Data Normality}

The variables in the dataset which have been measured on the interval scale like age and the dependent variable that was created to major the perceived impact of implementation of IFRS were tested for the normality. Normality was tested by applying both test and distribution method. As direct tests for normality Kolmogorov-Smirnov test and Shapiro-Wilk test have been used while for checking the distribution skewness and kurtosis of the relevant variables have been checked. The null hypothesis for Shapiro-Wilk test and Kolmogorov-Smirnov test is that the current distribution follows a normal distribution curve. The values for both the 
test in current scenario was found to be significant $(\mathrm{p}<.001)$ indicating us to reject null hypothesis and accept the alternate hypothesis. So based on Kolmogorov-Smirnov test and Shapiro-Wilk test we can say that the three variables that is age, experience and perceived impact of implementing IFRS are non-normal in nature.

\subsection{Validity and Reliability of Measurement Scale}

The questionnaire consisted of 32 items out of which 29 items were considered for item analysis while three items that is item number six (What do you think is the current status of IFRS in Banking industry?), item number 29 (What do you think would be the impediments to the convergence of IFRS?) and item number 31 (Are IFRS financial statements comparable?) were not considered for item analysis. This is because these questions consisted of selecting multiple options and were not measured on the interval scale, which was not case for other type of items in the questionnaire.

The Cronbach Alpha reliability for the 29 item scale was found to be 0.79 which can be considered a good measure of internal consistency of the scale. Corrected item total correlations of this scale (which are a major of item discrimination value of items) are shown in the Table 4 (in Appendix). According to (Field, 2010) if item total correlations are 0.4 or above then that item can be considered a significant item and can be retained for the further analysis. Based on this criteria around 11 items got eliminated which had their item total correlation values less than .4 (including the approximate values to decimals) leaving 18 items. The Cronbach alpha reliability value of scale was recalculated with these 18 items and found to be 0.85 .

\subsection{Factor Analysis}

One major aim of current research was to find out the major factors underlying the perceived challenges behind implementation of IFRS system in India. To find out the unobserved factors underlying the data and exploratory factor analysis using principle component method was carried out whose results are discussed below. As a precursor, the check for data sufficiency and suitability of data for factor analysis was done by observing the KMO test (Kaiser-Meyer-Olkin Measure of Sampling Adequacy) values and Bartlett's test of sphericity. KMO test is a test of data sufficiency whose recommended values are 0.7 or above (Field, 2010) while Bartlett's test of sphericity basically test the assumption whether our factor matrix is significantly different from identity matrix or not. For a meaningful factor analysis KMO tests value should be above 0.7 and Bartlett's test should be significant.

However, before going for factor analysis some more items were deleted because they were not matching to the objective of factor analysis, i.e., they were not assessing the impact of implementation of IFRS in India. They are item number 1(Are you aware of IFRS adoption procedure in India?) which measures awareness not impact, 2 (What do you think can be utility of IFRS in India?) which talks about the utility of the IFRS but not its impact, 11 (What do you think could be the impact on the ability to secure cross-border listing of securities by the Indian companies/Banks?), 16 (What do you think about the requirements of introducing amendments to the existing laws like Companies Act, RBI Act, SEBI Act, IRDA Act, etc.?), 20 (If we compare the "Fair value accounting" as described in IFRS/Ind AS and the "Historical Accounting" as described in Indian GAAP, what do you think will be the best method in Indian scenario?), 23 (Does Accounting Standard matter for the banks?), 27 (Is change in Accounting Standards sufficient to achieve shift in Accounting Outcomes?). After deleting these items once again Cronbach alpha value for remaining 13 items were calculated which came out to be .82 suggesting good reliability for the scale. Further all the items total correlations were above 0.4 recommended criteria in the final 13 item scale. An exploratory factor analysis was carried out on the 13 point scale whose results are presented in Table 5 (in Appendix).

A principal component analysis revealed for major factors underlying the perceived impact of implementation of IFRS in India. The varimax rotation was used and items below factor loading .5 were suppressed. According to (Field, 2010) variables having factor loading above .3 can be taken, however to avoid multiple loading the items having factor loading below .5 were suppressed but this did not lead to any loss of item or their contribution to the total variance explained. Also items having communalities less than .5 can be eliminated (Field, 2010) but in our case all the items reported communalities over .5. All of these factors had eigenvalue over one, the scree plot of the factors is shown in Figure 3 (in Appendix).

The first factor was named as 'performance implications' because the items contained in it were related to various types of performance-based implications for the banks after the implementation of IFRS system in India. The performance implication factor had eigenvalue of 4.39 and it contributed to $33.74 \%$ in the total variance. It contained items like Loan Impairment will affect the bank's financial performances after implementation of IFRS/Ind $\mathrm{AS}(.67, .79)$, transparency of the results of the company/banks after implementing IFRS/Ind AS will be impacted $(.72, .77)$, global operations of the company/banks after implementing IFRS/Ind AS will be impacted $(.53, .61)$, the accessibility of the Global Capital Market by the company/banks after implementing IFRS/Ind AS will be impacted $(.57, .57)$, implementation IFRS/Ind AS will affect the corporate governance aspect of the banks $(.54, .56)$.

The second factor concerned with the dissemination of financial information related to implementation of IFRS 
hence it was named as financial information implications. It contained items like implementation of IFRS/Ind AS will affect the financial information provided to the regulators $(.73, .84)$, implementation of IFRS/Ind AS will affect the financial information provided to shareholders $(.64, .72)$, the comparability aspect of financial statements after implementing IFRS/Ind AS will be affected $(.63, .62)$. This factor had the eigenvalue of 1.48 and explained $11.37 \%$ of total variance. The third factor was called economic growth implications because of two items contained in it indicated toward the impact of implementation of IFRS on economic growth and market capitalization of banks (which essentially is another measure of bank's economic growth). It contained 2 items, i.e., the implementation of IFRS/Ind AS have impact on economic growth of the country (.66, .79), implementing IFRS/Ind AS will affect the market capitalization of the banks $(.58, .71)$. This factor had the eigenvalue of 1.22 and explained $9.38 \%$ of variance. The third factor essentially indicated toward the human resource implications for the implementation of IFRS hence it was named as the human resource implications. This had an eigenvalue of 1.08 and explained it $8.34 \%$ of total variance. It contained 3 items like the training needs of the staff who oversees/monitor the process of implementing the IFRS/Ind AS will change $(.68, .78)$, the opportunities for the accounting professionals after implementing the IFRS/Ind AS will be affected $(.55, .73)$, and the flow of foreign direct investment (FDI) after implementing IFRS/Ind AS will be affected $(.66, .51)$.

\subsection{Regression Analysis}

A linear regression analysis was used to see the role of the demographic indicators recorded in the research over the perceived impact of implementation of IFRS in India. A new variable was created by adding the 13 items whose factor structure was established after factor analysis and named as 'perceived impact of implementing IFRS'. The demographic independent variables that were considered for the regression analysis were age, gender, experience, type of bank and designation of the respondent which is shown in table 6 (in Appendix). An analysis for diagnosing multicollinearity was also done to see if two or more independent variables are highly correlated with each other and if one can be predicted from the other. The VIF (variance inflation factor) value for all the variables was below 10 while the tolerance value for all the variables was not less than .1, so we can say there is no serious multicollinearity issue with the data. Looking at the results we can say that age and experience variables may be cause of concern for multicollinearity issue however the values of tolerance and VIF are within the prescribed cut-off limits for these two.

The regression analysis shows that none of demographic variables are influencing the respondents' perception about the impact of implementation of IFRS so we can say perceived impact is based not on the demographic variables. It might be the result of practical and experiential understanding of the respondents and not who he or she is.

\section{Conclusions}

This study examines implementing IFRS/Ind AS by PSBs in India. A large percent of our respondents indicated that IFRS-based financial statements will be used not only for external reporting but also for internal decision-making and performance measurement processes in the parent and subsidiaries. This approach to adopting IFRS/Ind AS may prompt an integration of financial accounting and management accounting practice in PSBs in India or even lead to an external reporting/financial accounting domination of internal reporting/management accounting. The impact of implementing IFRS on the financial statements is significant. For most companies in our sample, IFRS-based stockholders' equity is expected to be higher than equity based on national accounting standards. Most respondents believe that the change in accounting and reporting under IFRS, including the robust disclosure requirements, should improve comparability among PSBs and improve financial transparency. The stated benefits of the change, such as a lower cost of capital or improved quality and timeliness of management information, are questioned by many. Several important decisions within PSBs, including profit distribution policy and tax strategies, will still be based on individual accounts prepared in accordance with national accounting standards. There is a general consensus that transition to IFRS/Ind AS is costly, complex and burdensome process. The lack of implementation guidance and differences in interpretation of IFRS are other obstacles to accounting convergence. The consensus view of respondents is that a lack of adequate education, training, and knowledge of IFRS are important challenges of conversion. A training program for staff across a company is needed to let them adopt an entirely different system of business operations, performance measurement, and communication with the markets. This training will be an ongoing exercise since IFRS is a moving target. Audit firms play the crucial role in this training program. The involvement of auditors is so significant that they run the risk of becoming heavily involved in preparing the financial statements they are required to audit. This is mainly caused by the complexities of IFRS where many entities, especially smaller listed entities, lack sufficient expertise.

The scope of our study is limited to Public Sector Banks in India whereas the Banking sectors include the other scheduled commercial banks like private sector banks, Regional Rural Banks and Urban Cooperative Banks. 


\section{Appendix}

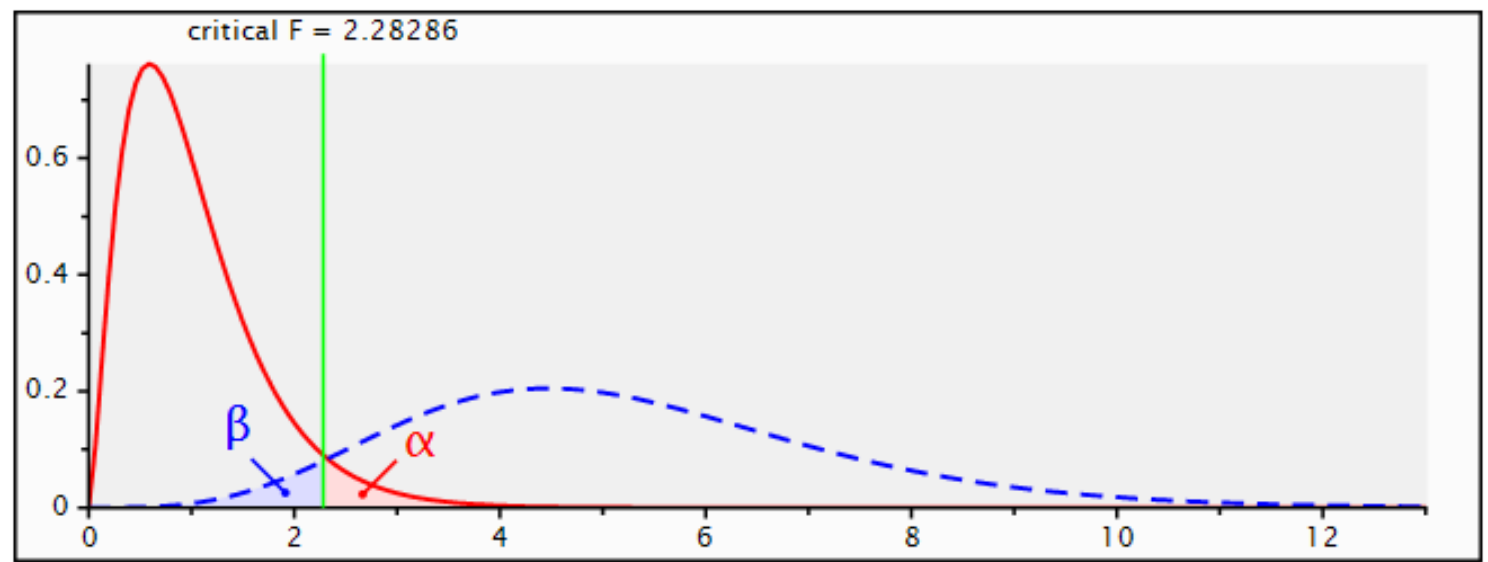

Figure 1. Graphical representation for the central and non-central for 5 predictors $(\alpha=.05)$.

Table 1. Description of independent/dependent variables used in the study

\begin{tabular}{|c|c|c|}
\hline \multicolumn{2}{|c|}{ Independent/demographic variables } & \multirow{2}{*}{ Dependent variable } \\
\cline { 1 - 2 } Name of variable & measurement scale & \\
\hline Age & Ordinal scale & \multirow{3}{*}{ perceived impact of implementation of IFRS accounting standards. It } \\
wender & Nominal scale & \\
\cline { 1 - 2 } Years of Experience & Ordinal scale & \\
\hline Designation & Ordinal scale & \\
\hline Name of bank & Nominal scale & \\
\hline Qualification & Nominal scale & \\
\hline Location & Nominal scale & \\
\hline
\end{tabular}

Table 2. Demographics of Survey Respondents $(\mathrm{N}=291)$

\begin{tabular}{|c|c|c|}
\hline Socio-demographics & $\begin{array}{c}\text { Frequency } \\
\mathbf{N}=\mathbf{2 9 1}\end{array}$ & $\begin{array}{c}\text { Percent } \\
\%\end{array}$ \\
\hline Gender & & 64.90 \\
\hline Male & 189 & 35.10 \\
\hline Female & 102 & 4.10 \\
\hline Age & & 35.10 \\
\hline $21-24$ years & 12 & 29.20 \\
\hline $25-34$ years & 102 & 21.60 \\
\hline $35-44$ years & 85 & 10 \\
\hline $45-54$ years & 63 & 29 \\
\hline $55-64$ years & & 12.70 \\
\hline Designation & 37 & 27.80 \\
\hline Officer & 81 & 28.20 \\
\hline Manager & 66 & 22.70 \\
\hline Senior Manager & 17 & 5.80 \\
\hline Chief Manager & 6 & 2.10 \\
\hline AGM & 2 & 0.70 \\
\hline DGM & & \\
\hline CMD & & \\
\hline Experience & & \\
\hline
\end{tabular}




\begin{tabular}{|c|c|c|}
\hline 0 to 5 years & 97 & 33.33 \\
\hline 6 to 10 years & 58 & 19.90 \\
\hline 11 to 15 years & 24 & 8.20 \\
\hline 16 to 20 years & 30 & 10.30 \\
\hline 21 to 25 years & 31 & 10.70 \\
\hline 26 to 30 years & 27 & 9.30 \\
\hline Over 30 years & 24 & 8.20 \\
\hline \multicolumn{3}{|l|}{ Type of Bank } \\
\hline Allahabad Bank & 3 & 1.00 \\
\hline Andhra Bank & 15 & 5.20 \\
\hline Bank of Baroda & 11 & 3.80 \\
\hline Bank of India & 11 & 3.80 \\
\hline Bank Of Maharashtra & 15 & 5.20 \\
\hline Canara Bank & 14 & 4.80 \\
\hline CBI & 11 & 3.80 \\
\hline Corporation Bank & 15 & 5.20 \\
\hline Dena Bank & 27 & 9.30 \\
\hline IDBI & 11 & 3.80 \\
\hline Indian Bank & 10 & 3.40 \\
\hline Indian Overseas Bank & 15 & 5.20 \\
\hline Oriental Bank Of Commerce & 19 & 6.50 \\
\hline Punjab National Bank & 30 & 10.30 \\
\hline Punjab \& Sind Bank & 20 & 6.90 \\
\hline State Bank of India & 23 & 7.90 \\
\hline Syndicate Bank & 10 & 3.40 \\
\hline UCO Bank & 7 & 2.40 \\
\hline United Bank Of India & 14 & 4.80 \\
\hline Vijaya Bank & 10 & 3.40 \\
\hline Allahabad Bank & 3 & 1.00 \\
\hline Andhra Bank & 15 & 5.20 \\
\hline Bank Of Baroda & 11 & 3.80 \\
\hline Bank Of India & 11 & 3.80 \\
\hline Bank Of Maharashtra & 15 & 5.20 \\
\hline Canara Bank & 14 & 4.80 \\
\hline CBI & 11 & 3.80 \\
\hline Corporation Bank & 15 & 5.20 \\
\hline Dena Bank & 27 & 9.30 \\
\hline IDBI & 11 & 3.80 \\
\hline Indian Bank & 10 & 3.40 \\
\hline
\end{tabular}




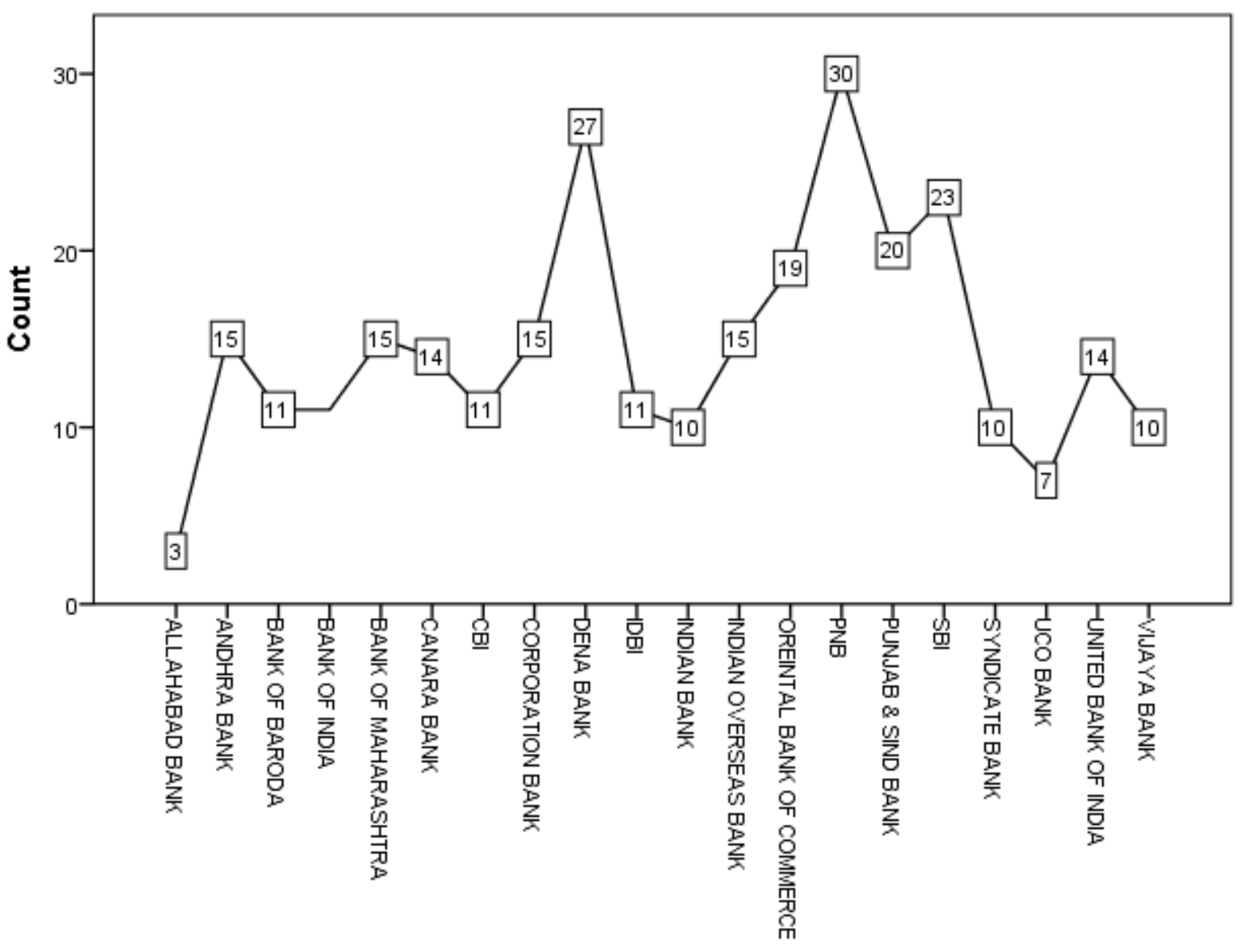

Organization

Figure 2. A line graph showing count of different organization type studied in the survey

Table 3. Test for Normality for the Variables in Research

\begin{tabular}{|c|c|c|c|c|c|}
\hline Variable name & $\begin{array}{c}\text { Kolmogorov-Smirnov test } \\
\text { value }\end{array}$ & $\begin{array}{c}\text { Shapiro-Wilk test } \\
\text { value }\end{array}$ & $\begin{array}{c}\text { P } \\
\text { value }\end{array}$ & Skewness/SE & Kurtosis/SE \\
\hline Age & 0.09 & 0.95 & $<.001$ & 1.77 & -3.87 \\
\hline Experience & 0.17 & 0.89 & $<.001$ & 3.35 & 4.25 \\
\hline $\begin{array}{c}\text { Perceived impact of implementing } \\
\text { IFRS }\end{array}$ & 0.15 & 0.93 & $<.001$ & 6.99 & 4.29 \\
\hline
\end{tabular}


Table 4. Item Total Correlation of Scale Items

\begin{tabular}{|c|c|}
\hline Items & $\begin{array}{l}\text { Corrected Item-Total } \\
\text { Correlation }\end{array}$ \\
\hline Q1. Are you aware of IFRS adoption procedure in India? & .358 \\
\hline Q2. What do you think can be utility of IFRS in India? & .643 \\
\hline Q3. What do you think about the problems in implementing the IFRS in Indian scenario? & -.241 \\
\hline Q4. What could be the problems in implementing the IFRS in Indian scenario? & .199 \\
\hline $\begin{array}{l}\text { Q5. What could be the ways to address these problems which might come in the process of implementing the } \\
\text { IFRS in Indian scenario? }\end{array}$ & .151 \\
\hline $\begin{array}{l}\text { Q7. What do you think could be the training needs of the staff who overseas/monitor the process of } \\
\text { implementing the IFRS/Ind AS? }\end{array}$ & .345 \\
\hline Q8. What do you think could be impact of IFRS/Ind AS on the financial information provided to shareholders? & .581 \\
\hline Q9. What do you think could be impact of IFRS/Ind AS on the financial information provided to regulators? &.$\underline{310}$ \\
\hline $\begin{array}{l}\text { Q10. What do you think could be the impact on the comparability aspect of financial statements after } \\
\text { implementing IFRS/Ind AS? }\end{array}$ & .406 \\
\hline $\begin{array}{l}\text { Q11. What do you think could be the impact on the ability to secure cross-border listing of securities by the } \\
\text { Indian companies/Banks? }\end{array}$ & .353 \\
\hline $\begin{array}{l}\text { Q12. What do you think would be the impact on the global operations of the company/Banks after } \\
\text { implementing IFRS/Ind AS? }\end{array}$ & .495 \\
\hline $\begin{array}{l}\text { Q13. What do you think would be the impact on the cost of capital of the company/Banks after implementing } \\
\text { IFRS/Ind AS? }\end{array}$ & .141 \\
\hline $\begin{array}{l}\text { Q14. What do you think would be the impact on the transparency of the results of the company/Banks after } \\
\text { implementing IFRS/Ind AS? }\end{array}$ & .585 \\
\hline $\begin{array}{l}\text { Q15. What do you think would be the impact on the accessibility of the Global Capital Market by the } \\
\text { company/Banks after implementing IFRS/Ind AS? }\end{array}$ & .512 \\
\hline $\begin{array}{l}\text { Q16. What do you think about the requirements of introducing amendments to the existing laws like Companies } \\
\text { Act, RBI Act, SEBI Act, IRDA Act, etc.? }\end{array}$ & .353 \\
\hline Q17. What do you think the implementation of IFRS/Ind AS have impact on economic growth of the country? & .391 \\
\hline $\begin{array}{l}\text { Q18. What do you think will the opportunities for the accounting professionals in implementing the IFRS/Ind } \\
\text { AS? }\end{array}$ & .297 \\
\hline $\begin{array}{l}\text { Q19. How 'Loan Impairment' will affect the bank's financial performances after implementation of IFRS/Ind } \\
\text { AS? }\end{array}$ & .477 \\
\hline $\begin{array}{l}\text { Q20. If we compare the "Fair value accounting" as described in IFRS/Ind AS and the "Historical Accounting" } \\
\text { as described in Indian GAAP, what do you think will be the best method in Indian scenario? }\end{array}$ & .384 \\
\hline $\begin{array}{l}\text { Q21. What do you think will be the impact of implementing IFRS/Ind AS on the corporate governance aspect of } \\
\text { the banks? }\end{array}$ & .407 \\
\hline Q22. What do you think will be the impact of IFRS/Ind AS on the Net Interest Margin (NIM) of the banks &.$\underline{158}$ \\
\hline Q23. Does Accounting Standard matter for the banks? & .573 \\
\hline $\begin{array}{l}\text { Q24. What do you think will be the impact of implementing IFRS/Ind AS on the market capitalization of the } \\
\text { banks? }\end{array}$ & .415 \\
\hline $\begin{array}{l}\text { Q25. What do you think will be the impact of implementing IFRS/Ind AS on the reporting discretion of the } \\
\text { accounting professionals? }\end{array}$ &.$\underline{230}$ \\
\hline Q26. What do you think whether IFRS should be 'Converged' or 'Harmonised'? & .333 \\
\hline Q27. Is change in Accounting Standards sufficient to achieve shift in Accounting Outcomes? & .443 \\
\hline $\begin{array}{l}\text { Q28. What do you think will be the impact on the flow of foreign direct investment (FDI) of implementing } \\
\text { IFRS/Ind AS? }\end{array}$ & .491 \\
\hline Q30. What do you think will be the impact of implementing IFRS/Ind AS on the level of earning management? & -.158 \\
\hline Q32. Will human resource cost increase after implementing IFRS/Ind AS? & .131 \\
\hline
\end{tabular}


Table 5. Exploratory Factor Analysis

\begin{tabular}{|c|c|c|c|c|}
\hline \multicolumn{5}{|c|}{ Exploratory Factor Analysis of items $(\mathrm{N}=\mathbf{2 9 1})$} \\
\hline Dimensions and Items & Communalities & $\begin{array}{l}\text { Factor } \\
\text { Loadings }\end{array}$ & Eigen Value & $\begin{array}{l}\text { Variance } \\
\text { Explained }\end{array}$ \\
\hline Factor1:Performance Implications & & & 4.39 & 33.74 \\
\hline $\begin{array}{l}\text { Q19. 'Loan Impairment' will affect the bank's financial } \\
\text { performances after implementation of IFRS/Ind AS. }\end{array}$ & 67 & .787 & & \\
\hline $\begin{array}{l}\text { Q14. Transparency of the results of the company/Banks after } \\
\text { implementing IFRS/Ind AS will be impacted. }\end{array}$ & .72 & .767 & & \\
\hline $\begin{array}{l}\text { Q12. Global operations of the company/Banks after implementing } \\
\text { IFRS/Ind AS will be impacted. }\end{array}$ & .53 & .606 & & \\
\hline $\begin{array}{l}\text { Q15. The accessibility of the Global Capital Market by the } \\
\text { company/Banks after implementing IFRS/Ind AS will be } \\
\text { impacted. }\end{array}$ & .57 & .569 & & \\
\hline $\begin{array}{l}\text { Q21. Implementation IFRS/Ind AS will affect the corporate } \\
\text { governance aspect of the banks. }\end{array}$ & .54 & .557 & & \\
\hline Factor 2: Financial information implications & & & 1.48 & 11.37 \\
\hline $\begin{array}{l}\text { Q9. Implementation of IFRS/Ind AS will affect the financial } \\
\text { information provided to regulators. }\end{array}$ & .73 & .838 & & \\
\hline $\begin{array}{l}\text { Q8. Implementation of IFRS/Ind AS will affect the financial } \\
\text { information provided to shareholders. }\end{array}$ & .64 & .715 & & \\
\hline $\begin{array}{l}\text { Q10. The comparability aspect of financial statements after } \\
\text { implementing IFRS/Ind AS will be affected. }\end{array}$ & .63 & .624 & & \\
\hline Factor 3: Economic Growth implications & & & 1.22 & 9.38 \\
\hline $\begin{array}{l}\text { Q17. The implementation of IFRS/Ind AS has impact on economic } \\
\text { growth of the country. }\end{array}$ & .66 & .793 & & \\
\hline $\begin{array}{l}\text { Q24. Implementing IFRS/Ind AS will affect the market } \\
\text { capitalization of the banks. }\end{array}$ & .58 & .714 & & \\
\hline Factor 4: Human Resource implications & & & 1.08 & 8.34 \\
\hline $\begin{array}{l}\text { Q7. The training needs of the staff who overseas/monitor the } \\
\text { process of implementing the IFRS/Ind AS will change. }\end{array}$ & .68 & .782 & & \\
\hline $\begin{array}{l}\text { Q18. The opportunities for the accounting professionals after } \\
\text { implementing the IFRS/Ind AS will be affected. }\end{array}$ & .55 & .727 & & \\
\hline $\begin{array}{l}\text { Q28. The flow of foreign direct investment (FDI) after } \\
\text { implementing IFRS/Ind AS will be affected. }\end{array}$ & .66 & .510 & & \\
\hline
\end{tabular}

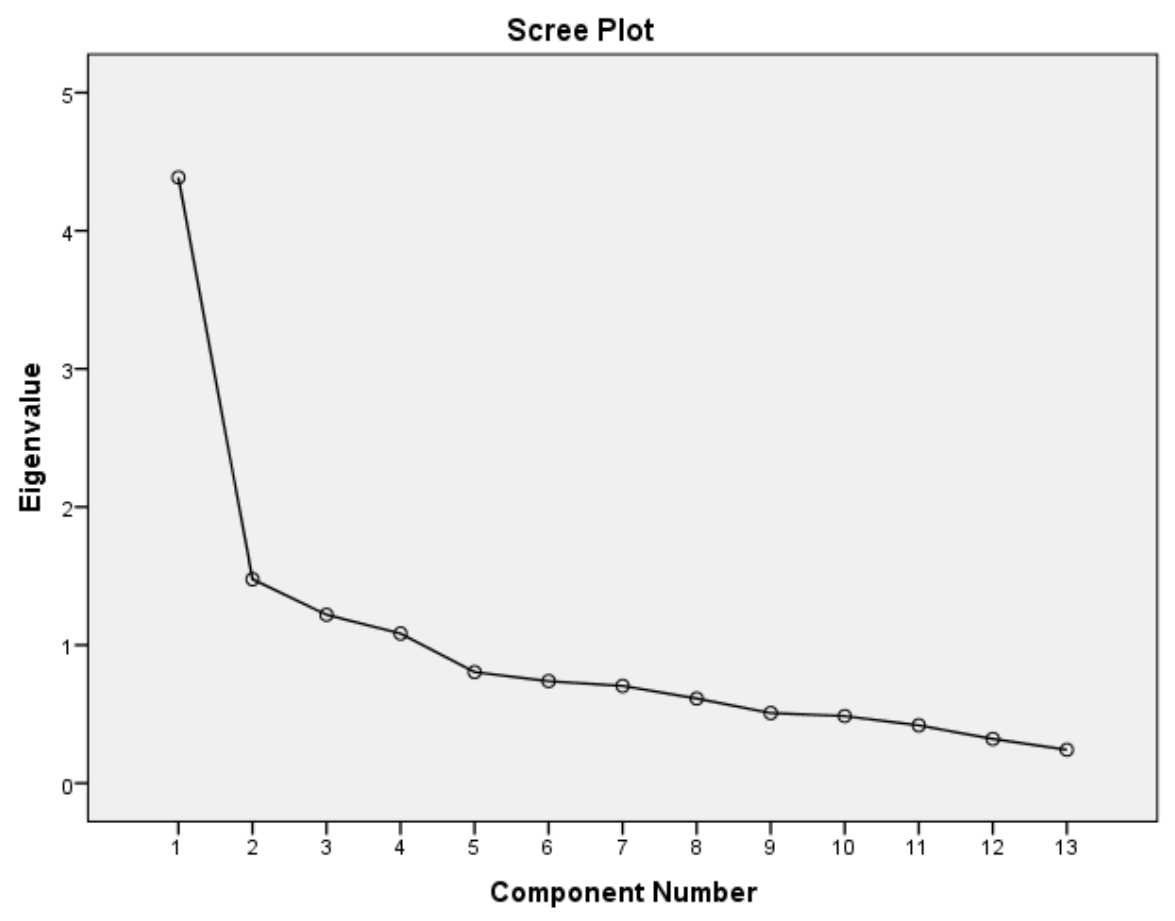

Figure 3. Scree plot showing the possible factor outcomes 
Table 6. Linear Regression model of demographic predictors of perceived impact of implementation of IFRS

\begin{tabular}{|c|c|c|c|c|c|c|c|}
\hline & & \multicolumn{4}{|c|}{ Model statistics } & \multicolumn{2}{|c|}{ Multicollinearity } \\
\hline & & $\mathrm{b}$ & SE B & $\beta$ & $\mathrm{p}$ & Tolerance & VIF \\
\hline \multirow{6}{*}{1} & (Constant) & 13.036 & 2.558 & & .000 & & \\
\hline & Age & .152 & .081 & .330 & .060 & .108 & 9.262 \\
\hline & Gender & 1.239 & .653 & .123 & .059 & .790 & 1.265 \\
\hline & Organization & -.032 & .054 & -.034 & .559 & .990 & 1.011 \\
\hline & Designation & .221 & .288 & .060 & .443 & .553 & 1.809 \\
\hline & Experience & -.056 & .079 & -.123 & .480 & .110 & 9.085 \\
\hline
\end{tabular}

Table 7. Testing for role of Gender on impact of IFRS

\begin{tabular}{|c|c|c|c|c|}
\hline Gender & N & Mean & Std. Deviation & Std. Error Mean \\
\hline Male & 189 & 20.1640 & 4.94540 & .35973 \\
\hline Female & 102 & 20.2255 & 4.60716 & .45618 \\
\hline
\end{tabular}

Table 8. Independent Samples Test

\begin{tabular}{|c|c|c|c|c|c|c|c|c|c|}
\hline & \multicolumn{2}{|c|}{$\begin{array}{c}\text { Levene's Test for Equality of } \\
\text { Variances }\end{array}$} & \multicolumn{7}{|c|}{ t-test for Equality of Means } \\
\hline & \multirow[t]{2}{*}{$\mathrm{F}$} & \multirow[t]{2}{*}{ Sig. } & \multirow[t]{2}{*}{$\mathrm{t}$} & \multirow[t]{2}{*}{ df } & \multirow{2}{*}{$\begin{array}{c}\text { Sig. } \\
(2 \text {-tailed) }\end{array}$} & \multirow{2}{*}{$\begin{array}{c}\text { Mean } \\
\text { Difference }\end{array}$} & \multirow{2}{*}{$\begin{array}{l}\text { Std. Error } \\
\text { Difference }\end{array}$} & \multicolumn{2}{|c|}{$\begin{array}{c}95 \% \text { Confidence Interval of } \\
\text { the Difference }\end{array}$} \\
\hline & & & & & & & & Lower & Upper \\
\hline $\begin{array}{l}\text { Equal variances } \\
\text { assumed }\end{array}$ & .812 & .368 & -.104 & 289 & .918 & -.06147 & .59341 & -1.22942 & 1.10648 \\
\hline $\begin{array}{l}\text { Equal variances } \\
\text { not assumed }\end{array}$ & & & -.106 & 219.970 & .916 & -.06147 & .58095 & -1.20640 & 1.08346 \\
\hline
\end{tabular}

Table 9. Co-relation between age and impact of IFRS

\begin{tabular}{|c|c|c|c|}
\hline \multicolumn{4}{|c|}{ Correlations } \\
\hline & & Age & impact_13 \\
\hline \multirow{3}{*}{ Age } & Pearson Correlation & 1 & $.202^{* *}$ \\
\hline & Sig. (2-tailed) & & .001 \\
\hline & $\mathrm{N}$ & 291 & 291 \\
\hline \multirow{3}{*}{ impact_13 } & Pearson Correlation & $.202^{* *}$ & 1 \\
\hline & Sig. (2-tailed) & .001 & \\
\hline & $\mathrm{N}$ & 291 & 291 \\
\hline
\end{tabular}

Table 10. Role of designation on IFRS

\begin{tabular}{|c|c|c|c|c|c|c|c|c|}
\hline \multicolumn{8}{|c|}{ Descriptives } \\
\hline & $\mathrm{N}$ & \multirow{2}{*}{ Mean } & \multirow{2}{*}{ Std. Deviation } & \multirow{2}{*}{ Std. Error } & \multicolumn{2}{|c|}{ 95\% Confidence Interval for Mean } & \multirow{2}{*}{ Minimum } & \multirow{2}{*}{ Maximum } \\
\cline { 5 - 8 } & & & & Lower Bound & Upper Bound & & \\
\hline Officer & 37 & 18.6216 & 3.91118 & .64299 & 17.3176 & 19.9257 & 14.00 & 30.00 \\
\hline Manager & 81 & 20.6173 & 4.95118 & .55013 & 19.5225 & 21.7121 & 13.00 & 36.00 \\
\hline Senior Manager & 82 & 19.5244 & 4.57914 & .50568 & 18.5182 & 20.5305 & 13.00 & 36.00 \\
\hline Chief Manager & 66 & 20.5909 & 4.94890 & .60917 & 19.3743 & 21.8075 & 13.00 & 36.00 \\
\hline AGM & 17 & 22.8235 & 4.55844 & 1.10559 & 20.4798 & 25.1673 & 17.00 & 30.00 \\
\hline DGM & 6 & 17.5000 & 3.44964 & 1.40831 & 13.8798 & 21.1202 & 13.00 & 22.00 \\
\hline CMD & 2 & 31.0000 & .00000 & .00000 & 31.0000 & 31.0000 & 31.00 & 31.00 \\
\hline Total & 291 & 20.1856 & 4.82164 & .28265 & 19.6293 & 20.7419 & 13.00 & 36.00 \\
\hline
\end{tabular}

Table 11. Anova

\begin{tabular}{|c|c|c|c|c|c|}
\hline & Sum of Squares & df & Mean Square & F & Sig. \\
\hline Between Groups & 547.765 & 6 & 91.294 & 4.186 & .000 \\
\hline Within Groups & 6194.215 & 284 & 21.811 & & \\
\hline Total & 6741.979 & 290 & & & \\
\hline
\end{tabular}




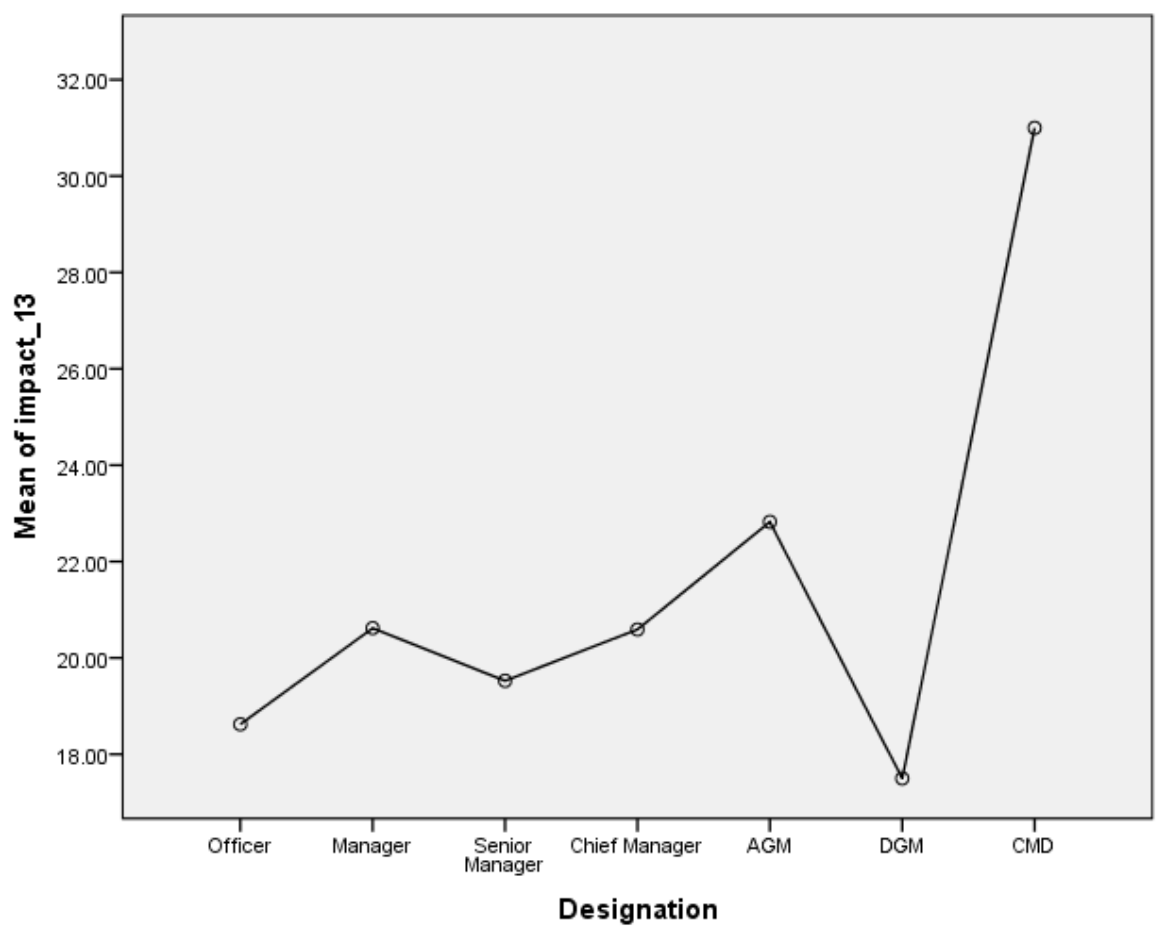

Figure 4.

Table 12. Role of Organization type on IFRS

\begin{tabular}{|c|c|c|c|c|c|c|c|c|}
\hline \multicolumn{9}{|c|}{ Descriptives } \\
\hline & \multirow{2}{*}{$\mathrm{N}$} & \multirow{2}{*}{ Mean } & \multirow{2}{*}{ Std. Deviation } & \multirow{2}{*}{ Std. Error } & \multicolumn{2}{|c|}{ 95\% Confidence Interval for Mean } & \multirow{2}{*}{ Minimum } & \multirow{2}{*}{ Maximum } \\
\hline & & & & & Lower Bound & Upper Bound & & \\
\hline Allahabad Bank & 3 & 20.0000 & 2.64575 & 1.52753 & 13.4276 & 26.5724 & 18.00 & 23.00 \\
\hline Andhra Bank & 15 & 18.9333 & 4.52717 & 1.16891 & 16.4263 & 21.4404 & 13.00 & 26.00 \\
\hline Bank of Baroda & 11 & 19.4545 & 4.10764 & 1.23850 & 16.6950 & 22.2141 & 14.00 & 28.00 \\
\hline Bank of India & 11 & 18.9091 & 3.30014 & .99503 & 16.6920 & 21.1262 & 15.00 & 26.00 \\
\hline $\begin{array}{c}\text { BANK OF } \\
\text { MAHARASHTRA }\end{array}$ & 15 & 19.4000 & 3.50102 & .90396 & 17.4612 & 21.3388 & 14.00 & 25.00 \\
\hline CANARA BANK & 14 & 22.5000 & 6.28490 & 1.67971 & 18.8712 & 26.1288 & 14.00 & 36.00 \\
\hline CBI & 11 & 24.0909 & 5.99090 & 1.80632 & 20.0662 & 28.1157 & 18.00 & 36.00 \\
\hline CORPORATION BANK & 15 & 19.5333 & 5.01237 & 1.29419 & 16.7576 & 22.3091 & 13.00 & 31.00 \\
\hline DENA BANK & 27 & 20.7037 & 5.12771 & .98683 & 18.6752 & 22.7322 & 14.00 & 36.00 \\
\hline IDBI & 11 & 19.8182 & 3.81623 & 1.15064 & 17.2544 & 22.3820 & 13.00 & 26.00 \\
\hline INDIAN BANK & 10 & 23.8000 & 5.92171 & 1.87261 & 19.5639 & 28.0361 & 18.00 & 36.00 \\
\hline $\begin{array}{c}\text { INDIAN OVERSEAS } \\
\text { BANK }\end{array}$ & 15 & 18.2000 & 4.27952 & 1.10497 & 15.8301 & 20.5699 & 13.00 & 26.00 \\
\hline $\begin{array}{l}\text { OREINTAL BANK OF } \\
\text { COMMERCE }\end{array}$ & 19 & 20.7368 & 5.76235 & 1.32197 & 17.9595 & 23.5142 & 14.00 & 36.00 \\
\hline PNB & 30 & 21.4667 & 5.48184 & 1.00084 & 19.4197 & 23.5136 & 13.00 & 36.00 \\
\hline PUNJAB \& SIND BANK & 20 & 19.0500 & 3.94001 & .88101 & 17.2060 & 20.8940 & 13.00 & 26.00 \\
\hline SBI & 23 & 19.9130 & 4.11111 & .85722 & 18.1353 & 21.6908 & 13.00 & 31.00 \\
\hline SYNDICATE BANK & 10 & 19.5000 & 4.47834 & 1.41618 & 16.2964 & 22.7036 & 13.00 & 25.00 \\
\hline UCO BANK & 7 & 19.1429 & 2.60951 & .98630 & 16.7295 & 21.5562 & 16.00 & 24.00 \\
\hline $\begin{array}{l}\text { UNITED BANK OF } \\
\text { INDIA }\end{array}$ & 14 & 19.0000 & 4.69042 & 1.25357 & 16.2918 & 21.7082 & 13.00 & 26.00 \\
\hline VIJAYA BANK & 10 & 18.4000 & 2.83627 & .89691 & 16.3711 & 20.4289 & 14.00 & 24.00 \\
\hline Total & 291 & 20.1856 & 4.82164 & .28265 & 19.6293 & 20.7419 & 13.00 & 36.00 \\
\hline
\end{tabular}


Table 13. Anova

\begin{tabular}{|c|c|c|c|c|c|}
\hline & Sum of Squares & df & Mean Square & F & Sig. \\
\hline Between Groups & 650.717 & 19 & 34.248 & 1.524 & .077 \\
\hline Within Groups & 6091.262 & 271 & 22.477 & & \\
\hline Total & 6741.979 & 290 & & & \\
\hline
\end{tabular}

\section{REFERENCES}

[1] Aharony, J., Barniv, R., Falk, H., 2010. The impact of mandatory IFRS adoption on equity valuation of accounting numbers for security investors in the EU. The European Accounting Review 19 (3), 535-578.

[2] Ailemen, I. O., \& Akande, A. O. (2012). International Financial Reporting Standard (IFRS): benefits, obstacles and intrigues for implementation in Nigeria. Business Intelligence Journal, 5 (2), 299-307.

[3] Albu, C. N., Nadia, A. L. B. U., PALI-PISTA, S. F., \& Vladu, D. C. (2011). The power and the glory of big 4: A research note on independence and competence in the context of IFRS implementation. POWER, 10(1), 43-54.

[4] Alexander, D., Britton, A., \& Jorissen, A. (2006). International Financial Reporting and Analysis. London: Thomson Learning

[5] Alp, A., \& Ustuntag, S. (2009). Financial Reporting Transformation the Experience of Turkey. Critical Perspective on Accounting, 20, 680-699.

[6] Alvares, C., \& Rawat, V. (2015, March). Decoding the new 'IFRS'. CFO India, 24-27.

[7] Ball, R. (2001). Infrastructure Requirements for an Economically Efficient System of Public Financial Reporting and Disclosure. Brookings Whartons Papers on Financial Services pp 127-69

[8] Bansal, A. \& Bansal, S. (2010). Challenges for IFRS implementations in India -An accounting revolution. International Journal of Research in Commerce and Management,1 (4), 113-126.

[9] Barniv, R. R., \& Myring, M. (2015). How would the differences between IFRS and U.S. GAAP affect U.S. analyst performance? Journal of Accounting and Public Policy, 34(1), 28-51. doi: http://dx.doi.org/10.1016/j.jaccpubpol.2014.10.003

[10] Barth, ME., Landsman, W. R., Lang, M. H., \& Williams, C. D. (2008). Accounting Quality: International. Accounting Standards and US GAAP. Retrieved from http://ssrn.com

[11] Bhargava, B. K. (1934). Indigenous Banking in Ancient \& Medieval India: D. B. Taraporevala sons.

[12] Bhattacharya, A. K. (2012). Essentials of Financial Accounting: Based on IFRS. New Delhi: PHI Learning.

[13] Borker, D. R. (2012). Accounting, Culture, And Emerging Economies: IFRS In The BRIC Countries. Journal of Business \& Economics Research, 10 (5), 313-324.
[14] Buchanan, R. F. (2003). International accounting harmonization: Developing a single world standard. Business Horizons. Retrieved from http://bqmena.com/en/media/get/20130304_BusHorizons.p df

[15] Chakrabarty, K. C. (2011, February, 11). Introduction of International Financial Reporting Standards (IFRS) - issues and challenges. BIS central bankers' speeches. Speech retrieved from http://www.bis.org/review/r110215b.pdf

[16] Chan, A. L. C., Hsu, A. W. H., \& Lee, E. (2015). Mandatory adoption of IFRS and timely loss recognition across Europe: The effect of corporate finance incentives. International Review of Financial Analysis, 38(0), 70-82. doi: http://dx.doi.org/10.1016/j.irfa.2015.02.002

[17] Choudhary, B., Gupta, R., \& Chauhan, H. (2012). Convergence of IFRS in India-Strategy, Benefits \& Challenges for Infrastructure Industry. Zenith International Journal of Business Economics and Management Research, 2(1), 140-147.

[18] Christopher S. Armstrong, Mary E. Barth, Alan D. Jagolinzer, and Edward J. Riedl (2010) Market Reaction to the Adoption of IFRS in Europe. The Accounting Review: January 2010, Vol. 85, No. 1, pp. 31-61.

[19] Clements, C. E., Neill, J. D., \& Stovall, O. S. (2010) Cultural diversity, country size and the IFRS adoption decision. The Journal of Applied Business Research, 26 (2), 115-126.

[20] Coch, L., \& French, J. (1948). Overcoming resistance to change. Human Relations, 1 (4), 512-32.

[21] Comrey, A. L., \& Lee, H.B. (1992). A first course in factor analysis. Hillsdale, NJ: Erlbaum.

[22] Daga, A. (2015). Key differences: IFRS and Indian GAAP. Retrieved 12 June 2015, from http://www.caclubindia.com/forum/key-differences-8211-if rs-and-indian-gaap-42290.asp\#.VXrUsvmqpHw

[23] Daniel, W. W. (1990). Applied Nonparametric Statistics. Boston: PWS-Kent.

[24] Datta, G. (1993). Pracina Bharata mem bainka vyavastha: Banking system in ancient India: Radha Publications.

[25] Deloitte. (2011). Indian GAAP, IFRS and Ind AS: A comparison.

[26] Delvaille, P., Ebbers, G., \& Saccon, C. (2005). International financial reporting convergence: Evidence from three Continental European countries. Accounting in Europe, 2(1), $137-164$.

[27] Dhankar, R. S., \& Gupta, A. (2014). Transition to International Financial Reporting Standards (IFRS) or IND AS in India. Global Journal of Finance and Management, $6(7), 609-614$ 
[28] Dholakia, P. (2012). A perpetual study of IFRS toward a true and fair view of International Accounting System. International Journal of scientific research and publication, $2(3), 1-9$

[29] Doupnik, T.S. \& Salter, S.B. (1995). External environment, culture and accounting practice: A preliminary test of a general model of international accounting development. International Journal of Accounting, 189-207.

[30] Dumontier, P., \& Raffournier, B. (1998). Why firms comply voluntarily with IAS: An empirical investigation with Swiss data. Journal of International Financial Management and Accounting, 9 (3), 15-26.

[31] Elrod, D., \& Tippett, D. (2002. The 'death valley' of change. Journal of Organizational Change Management, 15 (3), 273-91.

[32] Fechner, H.H.E., \& Kilgore, A. (1994). The influence of cultural factors on accounting practice. The International Journal of Accounting, 29, 265-277.

[33] Field, A. (2000). Discovering Statistics using SPSS for Windows. London - Thousand Oaks - New Delhi: Sage publications.

[34] Friedman, T. L. (2005). The world is flat: A brief history of the twenty-first century. New York: Farrar, Straus \& Giroux.

[35] Gajdhane, Amol. (2012). The Evolution Of Banking In India. Avishkar - Solapur University Research Journal, 2.

[36] Goyal, M. (2013). SMEs employ close to $40 \%$ of India's workforce, but contribute only $17 \%$ to GDP, Economic times.

[37] Grant, P. (1996). Supporting transition: How managers can help themselves and others during times of change. Organizations and People, 3 (1), 4.

[38] Guilford, J.P. (1954). Psychometric methods (2nd edition). New York: McGraw-Hill publications

[39] Gupta, K. (2004). Contemporary Auditing. New Delhi: McGraw-Hill Education (India) Pvt. Limited.

[40] Haribhakti, S. (2008). Financial accounting standards: Convergence of Indian standards with the global standards. International Journal of Disclosure and Governance, 5(3), 272-283.

[41] Hecke, T. V. (2012). Power study of anova versus Kruskal-Wallis test. Journal of Statistics and Management Systems, 15(2-3), 241-247.

[42] Henderson-Loney, J. (1996). Tuckman and tears: Developing teams during profound organizational change. Supervision, 57 (3), 5.

[43] Hofstede, G. (2009). Geert Hofstede Cultural Dimenstions, [Online] available at http://www.geert-hofstede.com/hofstede_dimensions.php.

[44] Holthausen, R. W. (2009). Accounting Standards, Financial Reporting Outcomes and Enforcement. Journal of Accounting Research, 47 (2), 447-458.

[45] Hope, O., Justin, J., \& Kang, T. (2006). Empirical Evidence on Jurisdictions that Adopt IFRS. Journal of International Accounting Research 5(2), 1-20.
[46] http://accountantsone.com/jobseekers/IFRS presentation.pd $\mathrm{f}$

[47] http://www.bis.org/review/r110215b.pdf

[48] Jain, P. (2011). IFRS implementation in India: Opportunities and challenges. World Journal of Social Sciences, 1 (1), 125-136.

[49] Jeanjean, T., \& Stolowy, H. (2008). Do accounting standards matter? An exploratory analysis of earnings management before and after IFRS adoption. Journal of Accounting and Public Policy, 27 (6), 480-494.

[50] Jermakowicz, E.K., \& Gornik-Tomaszewski, S. (2006). Implementing IFRS from the perspective of EU publicly traded companies. Journal of Accounting, Auditing and Taxation, 15, 170-96.

[51] Kamath, K. V. et al. (2003, July-September). Indian Banking Sector: Challenges and Opportunities. Vikalpa, 28.

[52] Kanhere, V., \& Murthy, G. (2007). Financial Reporting in India. Financial Reporting, 13 - 23.

[53] Kapoor, B., \& Ruhela, J. (2013). IFRS Implementation Issues and Challenges for India. VSRD International Journal of Business and Management Research, 3(2), 2319-2194.

[54] Kruskal, W. H. (1952). A nonparametric test for the several sample problem. The Annals of Mathematical Statistics, 23, 525-540.

[55] Kubler-Ross, E. (1969). On Death and Dying. Touchstone: New York, NY.

[56] Kulkarni, P., \& Raju, L. (2014). Implementation of IFRS in India: A study of awareness among practicing chartered accountants. Presidency Journal of Management Thought \& Research, 4 (1), 3-14.

[57] Kumar, P., \& Srivastav, S. (2012). International financial reporting standards: An overview. International Journal of Applied Financial Management Perspectives, 1(1), 23-29.

[58] Kumar, R. (2003). Essays on Ancient India: Discovery Publishing House Pvt. Limited.

[59] Larson, R. K., \& Kenny, S. Y. (1996). Accounting standard-setting strategies and theories of economic development: Implications for the adoption of International Accounting Standards. Advances in International Accounting, 9, 1-20.

[60] Larson, R. K., \& Street, D. L. (2004). Convergence with IFRS in an expanding Europe: Progress and obstacles identified by large accounting firms' survey. Journal of International Accounting, Auditing \& Taxation, 13, 89-119.

[61] Locke, L. F., Spirduso, W. W., \& Silverman, S. J. (2007). Proposals that work: A guide for planning dissertations and grant proposals (5th ed.). Thousand Oaks, CA: Sage.

[62] MacCallum, R.C., \& Widaman, K.F. (1999). Sample size in factor analysis. Psychological methods 1(4), 84 - 99

[63] Mann, H. B., \& Whitney, D. R. (1947). On a test of whether one of two random variables is stochastically larger than the other. The annals of mathematical statistics, 18 (1), 50-60.

[64] McEnroe, J. E., \& Sullivan, M. (2011). Individual investors' attitudes toward the acceptance of International Financial 
Reporting Standards in the United States. Journal of International Accounting, Auditing and Taxation, 20(1), 20-31. doi:

http://dx.doi.org/10.1016/j.intaccaudtax.2010.12.002

[65] Mirza, A. A. (2012). Wiley International Trends in Financial Reporting under IFRS: Including Comparisons with US GAAP, Chinese GAAP, and Indian GAAP: Wiley.

[66] Nandakumar, A., Ghosh, T. P., Mehta, K. J., \& Alkafaji, Y. A. (2010). Understanding IFRS fundamentals: International Financial Reporting Standards. New Jersey: John Wiley \& Sons, Inc.

[67] Nandy, D. (2010). Banking Sector Reforms in India and Performance Evaluation of Commercial Banks: Universal Publishers.

[68] Neuman, W. L. (1997). Social Research Methods: Qualitative and Quantitative Approaches. Boston: Allyn \& Bacon.

[69] Nguyen, J. (2015). What are some of the key differences between IFRS and U.S. GAAP? Retrieved 12 June 2015 , from http://www.investopedia.com/ask/answers/09/ifrs-gaap.asp

[70] Nobes, C., \& Parker, R. (2008). Comparative international accounting. Prentice Hall

[71] Nunnally, J.C. (1978). Psychometric theory. New Delhi: McGraw-Hill publications

[72] Palea, V. (2013). IAS/IFRS and financial reporting quality: Lessons from the European experience. China Journal of Accounting Research, 6(4), 247-263.

[73] Pavera, R., \& Khatri, J. (2008). IFRS: Implementation challenges and approach for banks in India. Retrieved from http://cab.org.in/CAB\%20Calling\%20Content/RISK\%20-\% 20Management $\% 20 \mathrm{in} \% 20$ Agriculture/IFRS-implementatio $\mathrm{n} \% 20$ Challenges\%20and\%20Approaches\%20for\%20Banks .pdf

[74] Peavy, D. E., \& Webster, S. K. (1990). Is GAAP the gap to international market? Management Accounting, 72, 31-35.

[75] Perera, D., \& Chand, P. (2015). Issues in the adoption of International Financial Reporting Standards (IFRS) for Small and Medium-Sized Enterprises (SMEs). Advances in Accounting, 31(1), 165-178. doi:

http://dx.doi.org/10.1016/j.adiac.2015.03.012

[76] Perera, M. H. B. (1989). Accounting in developing countries: A case for localised uniformity. British Accounting Review, $21,141-158$.

[77] Perlman, D., \& Takacs, G.J. (1990). The ten stages of change. Nursing Management, 21 4, 33-38.

[78] Perumpral, S. E., Evans, M., Agarwal, S., \& Amenkhienan, F. (2009). The evolution of Indian accounting standards: Its history and current status with regard to International Financial Reporting Standards. Advances in Accounting, incorporating Advances in International Accounting, 25, 106-111.

[79] Pilcher, R., \& Dean, G. (2009). Implementing IFRS in local government: Value adding or additional pain? Qualitative Research in Accounting \& Management,6(3), 180-196.
[80] Prasad, P. C. (2014). Foreign Trade and Commerce in Ancient India. New Delhi: Abhinav Publications.

[81] Price Water House Coopers. (2009). Similarities and differences: A comparison of IFRS, US GAAP and Indian GAAP*. Mumbai and Gurgaon: Price Water House Coopers.

[82] PricewaterhouseCoopers. (2006). Similarities and differences: A comparison of IFRS, US GAAP and Indian GAAP.

[83] Priyadarshini, S. (2012, May 7). Essay on the Major Banking Developments/Reforms After Independence. Retrieved from http://www.preservearticles.com/2012020722874/essay-onthe-major-banking-developmentsreforms-after-independenc e.html

[84] Radhika, H. (2015). Implementation of IFRS in India: Opportunities and challenges. International Journal of Research in Computer Application \& Management, 5 (4), 21-24.

[85] Ramanna, K., \& Sletten, E. (2009). Why do Countries Adopt International Financial Reporting Standards. Working Paper, Harvard Business School.

[86] Ramchandran, N., \& Kakani, R. K. (2007). Financial Accounting For Management. New Delhi: McGraw-Hill Education (India) Pvt Limited.

[87] Ramchandran, N., \& Kakani, R. K. (2011). Financial accounting for management. New Delhi: Tata McGraw-Hill Education.

[88] Rangaraju, S., \& Kennedy, S. H. (2012). Innovation in Management Challenges and Opportunities in the next decade: Allied Publishers.

[89] RAY, D. S. (2012). Indian GAAP and its convergence to IFRS: Empirical evidence from India. Advances in Applied Economics and Finance, 2(1), 257-276.

[90] Reserve Bank of India - Publications. (2015). Retrieved from https://rbi.org.in/scripts/publicationsview.aspx?id=10487

[91] Rezaee, Z., Smith, L. M., \& Szendi, J. Z. (2010) Convergence in accounting standards: Insights from academicians and practitioners. Advances in Accounting, 26 (1), 142-154.

[92] Riali-Belkaoui, A. (1995). Accounting information adequacy and macroeconomic determinants of economic growth: Cross-country evidence. Advances in International Accounting, 8, 87-98.

[93] Richter Quinn, L. (2004, April). Emerging pains. CA Magazine, 137(3), 30-36

[94] Rietveld, T. \& Van Hout, R. (1993). Statistical Techniques for the Study of Language and Language Behaviour. Berlin - New York: Mouton de Gruyter.

[95] Rohini, N. (2011). Are Indian Investors Aware of IFRS Standards?-A Study on the Investor's Attitude towards the Implementation of IFRS in India. International Journal of Global Business, 4(2).

[96] RSM-Astute, C. (n.d.). IFRS in India - Key Aspects. In R. A. Consulting (Ed.), (pp. 1 - 90). Mumbai: RSM Astute 
Consulting.

[97] Rudra, T., \& Bhattacharjee, D. (2011). Does IFRS influence earnings management? Evidence from India. Journal of Management Research, 4(1).

[98] Rundle-Thiele, S. (2005). Loyalty: An Empirical Exploration of Theoretical Structure in Two Service Markets. (Unpublished doctoral dissertation). University of South Australia, Adelaide.

[99] Schein, E. H. (1984). Coming to a New Awareness of Organizational Culture. Sloan Management Review, 25 (2), 3-16.

[100] Shah, K. K. (2014). IFRS and India: Opportunities and challenges. Global Journal of Multidisciplinary Studies, 3 (9), 165-188.

[101] Singh, S. (2013). Innovation is a heuristic to excellence: A study in Indian context. (Unpublished doctoral dissertation). University of Delhi, Delhi.

[102] Smith, M. (2008). Are International Financial Reporting Standards (IFRS) an Unstoppable Juggernaut for US and Global Financial Reporting? The Business Review, 10 (1), 25-31. Available at SSRN: http://ssrn.com/abstract=1125069.

[103] Soderstrom, N.S., Sun, K.J., 2007. IFRS adoption and accounting quality: a review. European Accounting Review $16(4), 675-702$

[104] Srivastava, A., \& Bhutani, P. (2012). IFRS in India: Challenges and opportunities. IUP Journal of Accounting Research \& Audit Practices, 11(2), 6.

[105] Sucher, P., \& jindrichovska, I. (2004). Implementing IFRS: A case study of the Czech Republic. Accounting in Europe, $1,109-141$

[106] Taylor, M. E., Evans, T. G., \& Joy, A. C. (1986). The impact of IASC accounting standards on comparability and consistency of international reporting practices. International Journal of Accounting Education and Research, 22(1), 1-9.

[107] Thappa, S. (2012). IFRS S in Indian Banking Industry: Challenges Ahead. International Journal of Finance and Accounting, 1(5), 94-105.

[108] The Indian Banking Sector: Recent Developments, Growth and Prospects. (January 2013). Delhi: Indian Brand Equity foundation.

[109] Tokar, M. (2005). Convergence and the Implementation of a Single Set of Global Standards: The Real-life Challenge. Accounting in Europe, 2(1), 47-68.

[110] United Nations. (2008). Practical implementation of international financial reporting standards: Lessons learned. New York and Geneva: United Nations Publication.

[111] Vakola, M., \& Nikolaou, I. (2005). Attitudes towards organizational change: What is the role of employees' stress and commitment? Employee Relations, 27 (2), 160-174.

[112] Wilcoxon, F. (1945). Individual comparisons by ranking methods. Biometrics Bulletin 1, 80-83.

[113] Yadav, S. \& Sharma, D. (2012). Convergence to IFRS What needs to be done by Indian corporate to meet the emerging challenges? International Journal of Computational Engineering \& Management, 15 (6), 36-43.

[114]Zeghal, D., \& Mhedhbi, K. (2006). An analysis of the factors affecting the adoption of international accounting standards by developing countries. The International Journal of Accounting, 41, 373-386.

[115] www.mca.gov.in

[116] www.icai.org

[117] www.rbi.gov.in

[118] www.sebi.gov.in 